\title{
Professionsstuderende i det interprofessionelle læringslandskab
}

(Ph.d.-forsvar: november 2017)

Cathrine Sand

Nielsen, lektor,

Sygeplejerske-

uddannelsen, VIA

University College

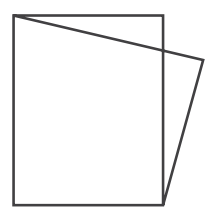

Modernisering af velfærdsstaten gennem tværprofessionelle samarbejdsformer får i disse år mærkbare konsekvenser for sundhedssektoren med krav om udvikling af tilsvarende tværprofessionelle uddannelsesforløb. Samtidig tydeliggøres politiske ønsker om at styrke samarbejdet på tværs af sektorer, således at også patient/ borgere og pårørende inddrages som partnere i behandlingsforløb.

Disse politiske ønsker og samfundsmæssige tendenser ligger til grund for det tværsektorielle uddannelsesprojekt kaldet InterTværs. Som projekt skal InterTværs udvikle og afprøve en model for et patient-/borgerorienteret, tværprofessionelt og tværsektorielt studieforløb på sundheds-professionsuddannelser.
Afhandlingen Professionsstuderende $i$ det interprofessionelle lœringslandskab fremlægges som resultat af et uddannelsesetnografisk feltarbejde relateret til projekt InterTværs. I årene 2014-2015 er InterTværs-forløb fulgt gennem fortløbende observation, samtaler, interview og materialeindsamling med særligt fokus på, hvordan studerende fra forskellige uddannelser samarbejder og Iærer gennem deltagelse i InterTværsforløb; hvordan de udvikler professionsidentitet, og hvordan de forskellige uddannelser og praktiksteder samarbejder om udvikling af InterTværs.

På denne baggrund fremlægges feltarbejdets resultater $\mathrm{i}$ afhandlingen som empiriske analyser, der både giver overblik over projekt InterTværs som uddannelsesprojekt og dækker de studerendes professionslæringsforløb. 
Analyserne giver indsigt i de studerendes læreproces og udvikling af professionsidentitet. Ved at referere såvel til forløbs-som studenterperspektivet analyseres og perspektiveres betingelserne for at udvikle InterTværs som model for professionslæring.

De uddannelsesetnografiske studier identificerer karakteristiske træk ved 'interprofessionel uddannelse' - eller 'tværprofessionelle uddannelseselementer', som det benævnes i feltet. De karakteristiske træk repræsenterer en position, hvor det at arbejde sammen på tværs såvel forstås som en metode, et læringsindhold, en organisering og en professionspædagogisk fundering.

Af empiriske bevæggrunde gennemføres analyserne indenfor en situeret tilgang til professionslæringsspørgsmålet, som det kommer til udtryk såvel i situeret læringsteori hos Jean Lave og Etienne Wengers, som i Kurt Aagaard Nielsen og Birger Steen Nielsens begreb om utopisk praksis og Yrjö Engeströms begreb om ekspansiv læring og virksomhedssystemer. Wolfgang Klafkis' begreb om dannelse (myndighed, solidaritet, selv- og medbestemmelse) inddrages for at skærpe den empiriske analyse relateret til projektspecifikke intentioner og vilkår.

I afhandlingen besvares feltforskningens spørgsmål indlejret i de empiriske analyser, der relateres til de uddannelsespolitiske makro-, meso- og mikroniveauer og gennemgående skelner mellem et organisatorisk perspektiv og et studenterperspektiv.

Afhandlingens analytiske rekonstruktion af projekt InterTværs afspejler bestræbelserne om at overkomme de udfordringer, der knytter sig til projektets krav om, at aktører fra hele fem uddannelser, forskellige hospitalsafdelinger og lokalcentre involveres. I den analytiske optik handler disse udfordringer om et komplekst samspil mellem projekt InterTværs' forsøg på at indfri bestræbelserne, de praktiske betingelser og modsætninger mellem de bestående instanser.

I afhandlingen fremstilles feltets reformudkast og involverede positioner i relation til deres ofte modstridende opfattelser af betydningen af at samarbejde på tværs. Hvad der er observeret, og i felten hørt omtalt som 'Et logistisk helvede', identificeres organisatorisk i samspil med en social lukkethed, der nærmest umuliggør at organisere InterTværs-forløb på tværs af uddannelser, praktiksteder og sektorer. På den baggrund bliver det en etnografisk pointe at kortlægge de udfordringer, feltet møder i det praktiske tværgående samarbejde. Udfordringer eksempelvis udløst af, at professions-uddannelsers og professioners selvbestemmelse udfordres af ude- og oppefra kommende krav. En underliggende bekymring om udvanding af professionsfagligheder og ikke mindst mangel på involvering og ejerskabsfølelse blandt undervisere på de enkelte uddannelser træder frem.

Analyserne følger projekt InterTværs fra det politiske udspring med krav om interprofessionel og tværsektoriel samarbejde til InterTværs' praktiske iværksættelse. Analysen af InterTværs-forløbet identificerer forløbets medspillere og modspillere og viser, hvordan projekt InterTværs fungerer som en indskudt platform mellem uddannelser og sundhedsvæsen, samt hvordan kliniske og teoretiske undervisere fra forskellige sektorer danner nye tværgående underviserpraksisfællesskaber. Viser videre, hvordan den indskudte platform for interprofessionalitet isoleres og kommer til at fungere som et reservat. Det fremprovokerede spørgsmål handler dernæst om InterTværs-modellen og forløbets bæredygtighed og fremtidsudsigter.

Forløbsanalysen fastholder kardinalpunkter i de studerendes læreproces og viser, hvordan InterTværs-forløb for de studerende fungerer som en nyskabt murstensløs læringskontekst, hvor patient/borgeren indgår som samlingskraft. Forløbsanalyserne suppleres af næranalyser af, hvordan de studerende udvikler professionsidentitet igennem specifikke erfaringer. Næranalyser af eksemplariske hændelsesforløb viser, hvordan de studerende spejler sig og 'det professionelt rigtige' i de andre professioners studerende, i patient/ borgerens forventninger samt i praktiksteders praksisser.

Analyserne viser, hvordan den uddannelseskonventionelle monoprofessionelle læringskontekst med InterTværs' iværksættelse forskydes til en nyskabt patient-/borgerorienteret, interprofessionel og tværsektoriel læringskontekst. Viser videre, hvordan forskydningen problematiseres, idet de studerende opfatter den nye læringskontekst som urealistisk og InterTværs-forløbet som et utopisk værksted og fristed. I så henseende opfattes forholdet mellem en 'urealistisk' læringskontekst omkring patient-/borgerforløbet og så praktikstedernes 'rigtige' virkelighed at kollidere med såvel de organisatoriske som pædagogiske realiteter. 
Tema: Professionshøjskoler i 10 år

Et empirisk hovedfund er de studerendes ambivalens i bevægelsen mellem at lære at gøre som mesteren i den monoprofessionelle praksis og skabelsen af en ny interprofessionel praksis, hvor professionsidentitet udfordres. Analyserne viser, hvordan de studerende udspændt mellem engagement i egen monoprofessionelle mesterlære og den eksperimenterende, interprofessionelle læringstilgang søger ud af ambivalensen ved at engagere sig ét sted ad gangen frem for at håndtere balancen. Udvikling af 'ambivalenstolerance' med evne til at udholde og omgås sociale konflikter og modsigelser, samt anticipationsevne bliver central i dannelsesprocessen. Det handler så at sige om, at de studerende lærer at håndtere ambivalensen.

Analyserne viser, hvordan de studerende med InterTværs-forløb indskudt som utopisk værksted principielt gives plads til bearbejdelse af ambivalenserne gennem dialog mellem det monoprofessionelle og interprofessionelle og tværsektorielle i det fælles fokus på patient-/ borgerforløbet. Der gives mulighed for, at de studerende på den ene side utvungent kan komme i spil med hinanden og det fælles tredje, mens de samtidig og på den anden side netop forpligtes af et konkret patient-/borgerforløb. Når de studerende går ind $\mathrm{i}$ ambivalensen og møder de uforenelige modsætninger med konkrete forhandlinger om det fælles tredje i form af 'fælles mål der er patientens mål', samt med 'fælles klinisk beslutningstagning' og ved at skabe konkret 'sammenflettet praksis', muliggøres åbning af ambivalensforsvaret og en bevægelse mod ambivalenstolerance. Samtidig og omvendt forstærker tidsforbruget til fælles refleksion netop oplevelsen af det urealistiske.

Afhandlingen viser, hvordan projekt InterTværs' intention er en insisteren på, at uddannelse og pædagogik ikke alene har til opgave at tilpasse de studerende til det eksisterende sundhedsvæsen, men tillige må ses som et potentielt vigtigt aspekt i sundhedsvæsenets forandringsproces. Viser videre, hvordan projekt InterTværs nok går forrest i skabelsen af et nyt patient-/borgerorienteret uddannelseselement og søger at balancere mellem mono- og interprofessionel patient-/borgerorienteret beslutningstagning på tværs af sektorer, men samtidig netop her møder modsætninger. 